\title{
Predictors of Neurodevelopmental Outcomes in Newborns Undergoing Hypothermia Therapy
}

\author{
Min-Kyo Chun ${ }^{1}$, Hyun-Jung Sung ${ }^{1}$, Joo-Hyung Park ${ }^{1}$, Gye-Yeon Lim ${ }^{2}$, and So-Young Kim ${ }^{1}$ \\ Departments of ${ }^{1}$ Pediatrics and ${ }^{2}$ Radiology, College of Medicine, The Catholic University of Korea, Seoul, Korea
}

\section{ABSTRACT}

Purpose: This study aimed to identify the early predictors of neurodevelopmental outcomes in infants undergoing therapeutic hypothermia for neonatal hypoxic ischemic encephalopathy.

Methods: The medical records of 24 neonates who underwent hypothermia therapy for hypoxic ischemic encephalopathy at the neonatal intensive care unit of Yeouido St. Mary's Hospital of the Catholic University of Korea between August 2013 and May 2016 were reviewed. Patients were divided into two groups according to their neurological outcome at the age of 18 to 24 months: a normal group $(n=14)$, which included patients with normal neurological function, and an abnormal group $(n=10)$, which included patients with neurological deficits. The clinical characteristics, clinical outcomes, and laboratory findings before and after hypothermia treatment were compared between the groups.

Results: There were no significant differences in the demographic characteristics between the two groups. With regard to clinical outcomes, only brain magnetic resonance imaging (MRI) findings showed significant differences between the normal and abnormal groups $(21.4 \%$ vs. $100.0 \%, P<0.001)$. With regard to laboratory findings, there were significant differences in the white blood cell (WBC) count after hypothermia treatment between the normal and abnormal groups (9.78 \pm 3.52 vs. $14.90 \pm$ $3.48, P=0.003)$. However, logistic regression analysis showed that the WBC count was not an independent risk factor for abnormal neurodevelopment $(P>0.05)$.

Conclusion: The presence of abnormal lesions on MRI was the most useful predictor of poor neurodevelopmental outcome in infants treated with therapeutic hypothermia after perinatal asphyxia.

Key Words: Newborn; Hypoxia-ischemia, brain; Hypothermia treatment ; Magnetic resonance imaging; Treatment outcome; Risk factors

\section{서론}

저체온치료법은 대규모 다기관 무작위 대조 임상시험에서 주산기 저산소증으로 인한 중등도
Received: 8 August 2018

Revised: 11 October 2018

Accepted: 13 November 2018

Correspondence to: So-Young Kim

Departments of Pediatrics, Yeouido St.

Mary's Hospital, College of Medicine,

The Catholic University of Korea, 10 63-ro, Yeongdeungpo-gu, Seoul 07345 , Korea

Tel: +82-2-3779-1043

Fax: +82-2-783-2589

E-mail: sykimped@catholic.ac.kr https://orcid.org/0000-0002-3244-6061

Copyright(c)

By Korean Society of Neonatology.

All right reserved.

This is an Open-Access article distributed under the terms of the Creative Commons Attribution Non-Commercial License (http://creativecommons.org/licenses/ by-nc/4.0), which permits unrestricted non-commercial use, distribution, and reproduction in any medium, provided the original work is properly cited. 
혹은 중증의 저산소허혈뇌증이 있는 신생아의 사망률 및 생후 18 개 월 시기 중증장애의 발생빈도를 의미 있게 감소시키는 결과를 보임 으로서 신생아 저산소허혈뇌증 치료방법 중 유일하게 입증된 효과 적인 신경보호 치료법이다 ${ }^{1-4)}$. 이 치료법은 2010년 중등도 이상 저산 소허혈뇌증 신생아를 위한 표준치료법으로 제안된 이후 국제적으로 사용되고 있으며 국내에는 2012년부터 도입되었다. 그러나 저체온 치료법의 개발 및 시행에도 불구하고 출생 시 중등도 이상의 저산소 허혈뇌증을 가진 신생아들의 사망 또는 중대한 장애로의 이환율은 아직 높아 영, 유아기 신경 발달 장애와 사망의 가장 중요한 원인으 로 남아있다 ${ }^{3-5)}$. 저체온치료법의 확산에 따라 출생 직후 저산소허혈 뇌증으로 저체온치료를 받은 환아들을 대상으로 치료 효과를 확인 하고 장기적인 신경학적 예후를 예측할 수 있는 객관적인 예후인자 에 대한 필요성이 대두되고 있으며 ${ }^{(-8)}$ 현재 혈액검사, 진폭통합뇌파 검사(amplitude-integrated electroencephalography, aEEG) 등을 그 예후인자로 확인하고자 하는 연구들이 진행되고 있다. 초기 치료 과 정 중의 신경 손상 정도나 신경 발달 장애를 예측할 수 있는 인자의 발견은, 특정 치료군에 대한 치료 계획과 보조 치료 일정 등에 대한 접근을 효율적으로 시행하는데 도움이 될 것이달.

본 연구자들은 저체온치료를 받았던 신생아들을 대상으로 분만 및 출생과 관련한 임상적 특성과 치료 과정 중의 임상증상, 치료 이전 과 치료 이후의 혈액 및 생화학적 결과, 뇌 자기공명영상(magnetic resonance imaging, MRI)의 결과들 중 신경 발달 예후와 관련이 있 는 인자가 있는지 알아보고자 하였다.

\section{대상 및 방법}

본 연구는 가톨릭의대 여의도성모병원 기관생명윤리위원회의 승 인을 받았다. 2013년8월부터 2016년 5월까지 가톨릭의대 여의도성 모병원 신생아 집중치료센터에서 저산소허혈뇌증으로 입원하여 저 체온치료를 받았던 신생아 29명 중 신경 발달 검사 이전 사망한 환자 3 명과 추적 관찰이 안 된 2 명을 제외하고 생후 18 개월에서 24 개월 시기 신경학적 검사 추적 관찰이 가능하였던 환자 24 명을 대상으로 의무기록을 후향적으로 분석하였다.

대상아들은 National Institute of Child Health and Human Development (NICHD)의 전신 저체온치료 방법(whole body hypothermia protocol) $)^{4)}$ 에 따라 재태주령 36 주 이상, 출생체중 $1,800 \mathrm{~g}$ 이상 환아들 중, 대사성산증, 낮은 아프가점수, 신경학적 검진상 중등도 이상의 저산소허혈뇌증으로 판정된 경우, 생후 6시간 이내에 저온 의 전신 매트를 이용하여 신생아의 중심 체온을 $33.5^{\circ} \mathrm{C}$ 로 낮추어 72 시간 유지시키는 저체온치료를 시행하였다. 각 대상아들의 재태기 간, 출생체중, 성별, 신생아 저산소허혈뇌증 중증도, 분만 방법, 산모 의 나이, 분만 중 태아의 뇌 손상을 유발할 수 있는 주요 위험 사건,
양수의 태변 유무, 출생 후 저체온치료 시작까지 시간, 계면활성제 투여, 저체온치료 중 최저 혈압, 최저 맥박수, 승압제 투여, 스테로이드 투여, 기흥, 폐출혈, 지속성 폐동맥 고혈압증, 경련, 뇌파검사(electroencephalography, EEG) 결과, 그 외에 주산기 또는 분만과 연관 된 주요 요인 등을 분석하였다. 혈액학적 검사는 치료 시작 이전과 치료 완료 이후의 혈액학, 혈액 가스, 혈액 화학, 출혈 요인 등의 결 과를 비교 분석하였다. 모든 대상아들은 생후 7-14일에 뇌 MRI로 고 식적 영상과 확산 강조 영상을 함께 찍었다. 촬영된 영상은 한 명의 소아영상의학과 전문의에 의하여 판독되었다.

뇌신경 발달 평가는 교정 연령 18-24개월 시행한 한국 영유아발 달선별검사(Korean Developmental Screening Test for infants and children, K-DST), Bayley 영아발달검사-II (Bayley Scales of Infant Development, BSID-II), 혹은 소아재활의학과 전문의에 의한 신경 학적 검사들 중 각 대상아들에게 시행된 검사에 따라 기준을 정하여 평가하였다. K-DST는 출생 후 4 개월마다 시기에 맞는 K-DST를 시 행하였으며 전원 소아재활의학과 전문의의 추적 관찰을 시행하였 다. K-DST는 영유아의 5가지 발달 영역(의사소통, 대근육 운동, 소 근육 운동, 문제 해결, 개인-사회성)에 대한 부모의 답변을 받아 발달 영역별로 각 6 가지 문항의 점수를 합산하여, 주어진 월령별 절선 점 수와 비교하였다. 한 개 이상의 발달 영역에서 절선 점수보다 낮은 점수를 얻은 경우 '발달 지연 의심'이라고 판정을 내린 후 재활의학 과에 의뢰하였다. BSID-II를 교정 연령 18-24개월 시행 한 경우 지능 발달 지수(mental developmental index)가 70 미만 또는 운동 발달 지수(psychomotor developmental index)가 70 미만이면 의미 있는 발달 지연이 있는 것으로 진단하였다. 소아신경 담당 전문의와 재활 의학과 전문의에 의해 신경학적 검사를 시행하여 사지 중 어느 하나 가 비 진행적인 경직성(spastic) 또는 근 이상성(dystonic) 근육 수축, 또는 자세 유지 장애 및 운동 장애가 있는 경우 뇌성마비로 진단하 였다. 모든 대상아는 퇴원 전 뇌간유발반응 청력검사(brain evoked response audiometry)를 시행하고 이상이 있는 경우에는 생후 6개 월까지 2-3회 추가로 실시 후, 지속적인 이상이 있을 때 감각신경성 난청으로 진단하였다. 시각 발달은 시각 교정을 한 상태에서 더 좋 은 쪽 시력이 20/200 이하인 심각한 시각 장애가 있는 것으로 정의하 였다. 발달 지연, 뇌성마비와 감각신경성 난청, 시각장애 중 하나 이 상 있으면 나쁜 뇌신경 발달(poor neurodevelopmental outcome)을 가지는 것으로 정의하였다.

\section{1. 통계 분석}

통계 분석은 SPSS version 22.0 (IBM Co., Armonk, NY, USA) 통계 프로그램을 이용하였다. 대상아의 뇌신경 발달 평가 소견 상 정상 그 룹과 비정상 그룹으로 나누어 Student $t$-test, chi-square test, Fisher's exact test로 비교 분석하였다. 비정상 MRI 소견을 뇌 손상 형태에 따 라 분류하고 이 분류에 따른 뇌신경 발달 예후의 차이를 분석하였 
다. 통계적 유의 수준은 $P<0.05$ 로 하였다.

\section{결과}

\section{1. 일반적 특성 비교}

저체온치료를 받고 교정 연령 18-24개월에 신경 발달검사를 시행 한 대상아 24 명 중 정상 발달을 보인 그룹은 14 명, 비정상 발달을 보 인 그룹은 10 명이었다. 양 군 간의 재태주령, 출생체중, 성별, 분만 장소, 분만 방법, 분만 중 태아의 뇌 손상을 유발할 수 있는 주요 사 건, 신생아 저산소허혈뇌증 중증도, 출생 후 저체온치료 시작 시간, 자궁 내 발육지연, 양수 내 태변, 계면활성제 투여 등에 양 군 간 통 계적으로 유의한 차이가 없었다(Table 1).

\section{2. 임상적 특성 비교}

저체온치료 중 최저 평균혈압 및 최저 맥박 수, 승압제 투여군, 스 테로이드 투여군에 양 군 간 차이가 없었으며 경련, 기흥, 폐출혈, 폐 동맥 고혈압증, 비정상 뇌파 소견의 동반, 기계적 환기 치료를 받은 기간 및 입원기간 또한 양 군 간 유의한 차이가 없었다(Table 2). 생 후 7-14일 시행한 MRI 결과는 정상 발달군 14명 중 3명(21.4\%)에서 비정상 발달군 10 명 중 10 명 $(100 \%)$ 에서 비정상 소견을 보여 양 군 간 통계학적으로 유의한 $(P<0.001)$ 차이를 보였다(Table 2).

\section{3. 치료 전과 치료 후 혈액검사 비교}

저체온치료 시작 전 정상 발달군과 비정상 발달군의 혈액검사 시

Table 1. Clinical Characteristics of Neonates Who Showed Normal vs. Abnormal Development

\begin{tabular}{lccc}
\hline Variable & $\begin{array}{c}\text { Normal } \\
(\mathrm{n}=14)\end{array}$ & $\begin{array}{c}\text { Abnormal } \\
(\mathrm{n}=10)\end{array}$ & $\begin{array}{c}P \text { - } \\
\text { value }\end{array}$ \\
\hline GA (wk) & $39.3 \pm 1.5$ & $39.4 \pm 1.3$ & 0.923 \\
Birth weight (g) & $3,180 \pm 220$. & $3,180 \pm 510$ & 0.984 \\
Male sex & $11(78.6)$ & $6(60.0)$ & 0.393 \\
Delivery place Inborn & $7(50.0)$ & $3(30.0)$ & 0.421 \\
Mode of delivery vaginal & $7(50.0)$ & $4(40.0)$ & 0.095 \\
Maternal age (yr) & $30.10 \pm 3.35$ & $34.14 \pm 4.06$ & 0.057 \\
Presence of sentinel event, yes & $9(64.3)$ & $5(50.0)$ & 0.678 \\
Sarnat staging & & & 0.240 \\
Stage 2 & $12(85.7)$ & $8(80.0)$ & \\
Stage 3 & $2(14.3)$ & $2(20.0)$ & \\
Postnatal age at initiation (hr) & $4.1 \pm 1.5$ & $3.4 \pm 2.0$ & 0.345 \\
Intrauterine growth retardation & $1(7.14)$ & $3(30.0)$ & 0.253 \\
Meconium staining & $8(57.14)$ & $2(20.0)$ & 0.197 \\
Surfactant use, yes & $8(57.1)$ & $4(40.0)$ & 0.680 \\
\hline
\end{tabular}

Values are expressed as mean \pm standard deviation or number (\%).
행 시간은 각각 평균 $3.11 \pm 2.09,2.43 \pm 1.74$ 시간으로 양 군 간 차이가 없었다. 치료 전 혈액의 $\mathrm{PH}, \mathrm{HCO}_{3}$, Base deficit, Glucose, Creatinine, Calcium, AST, ALT, LDH, CPK, C-reactive protein (CRP), WBC, Hct, Platelet, PT, aPTT 모두 양 군 간 유의한 차이가 없었다(Table 3). 치 료 완료 후 양 군의 혈액검사 시행 시 나이 또한 유의한 차이가 없었 다. 백혈구 수치는 저체온치료 이전에는 양 군 간 차이가 없었던 것 에 비하여 치료 이후의 결과는 비정상 발달군이 정상군에 비하여 통계적으로 유의하게 높았다( $14.22 \pm 4.32$ vs. $9.55 \pm 3.41, P<0.05)$ (Table 3). 치료 이후의 다른 혈액검사들의 결과는 양 군 간에 유의 한 차이가 없었다(Table 3). 단일 변수 비교에서 의미가 있었던 백혈 구 수치로 시행한 로지스틱 회귀분석 결과 유의한 영향을 미치지 않 는 것으로 나타났다 $(P>0.05)$.

\section{4. 뇌 MRI 결과 비교}

정상 발달군은 14 명 중 3 명 만이 비정상 뇌 $\mathrm{MRI}$ 의 소견을 보인 반 면 비정상 발달군은 10 명 모두 비정상 뇌 MRI의 소견을 보여 양 군 간 MRI 결과가 통계적으로 의미 있는 차이를 보였다 $(P<0.001)$ (Table 2). MRI 소견을 분석해 보면 비정상 발달군은 10 명 중 7 명에서 뇌실 질의 병변과 출혈이 동반되었으나, 3 명의 영아는 실질 손상 없이 경 막하출혈 소견만 보였다. 정상 발달군 중 2명은 출혈 소견 없이 뇌실질 의 이상 소견만 보였고 1 명이 경막하출혈 소견을 보였다(Table 4).

\section{고찰}

저체온치료는 저산소허혈뇌증에 이환된 만삭 신생아의 신경 발

Table 2. Clinical Outcomes of the Normal vs. Abnormal Groups

\begin{tabular}{lccc}
\hline Variable & $\begin{array}{c}\text { Normal } \\
(\mathrm{n}=14)\end{array}$ & $\begin{array}{c}\text { Abnormal } \\
(\mathrm{n}=10)\end{array}$ & $\begin{array}{c}P \text { - } \\
\text { value }\end{array}$ \\
\hline MBP (lowest, during hypothermia) & $37.1 \pm 7.0$ & $39.0 \pm 6.0$ & 0.490 \\
HR (lowest, during hypothermia) & $81.1 \pm 14.0$ & $77.6 \pm 10.0$ & 0.491 \\
Dopamine infusion, yes & $9(64.3)$ & $6(60.0)$ & 1.000 \\
Steroid therapy, yes & $4(28.6)$ & $4(40.0)$ & 0.657 \\
Neonatal seizure, yes & $7(50.0)$ & $5(50.0)$ & 1.000 \\
Pneumothorax, yes & $4(28.6)$ & $2(20.0)$ & 0.631 \\
Pulmonary hemorrhage, yes & $1(7.1)$ & 0 & 1.000 \\
Pulmonary hypertension, yes & $2(14.3)$ & $2(20.0)$ & 0.578 \\
Abnormal EEG & $3(21.4)$ & $5(50)$ & 0.078 \\
Brain MRI abnormal lesion & $3(21.4)$ & $10(100)$ & 0.000 \\
Length of mechanical ventilation (d) & $10.4 \pm 6.8$ & $7.4 \pm 3.8$ & 0.178 \\
Length of hospital stay (d) & $24.4 \pm 9.3$ & $19.7 \pm 5.6$ & 0.140 \\
\hline
\end{tabular}

Values are expressed as mean \pm standard deviation or number (\%). Abbreviations: MBP, mean arterial blood pressure; HR, heart rate; EEG, electroencephalography; MRI, magnetic resonance imaging. 
Table 3. Laboratory Data of the Normal vs. Abnormal Groups

\begin{tabular}{|c|c|c|c|c|c|c|}
\hline \multirow{2}{*}{ Variable } & \multicolumn{3}{|c|}{ Before treatment } & \multicolumn{3}{|c|}{ After treatment } \\
\hline & Normal $(n=14)$ & Abnormal $(n=10)$ & $P$-value & Normal $(n=14)$ & Abnormal $(n=10)$ & $P$-value \\
\hline Postnatal age (hr) & $2.4 \pm 1.7$ & $3.1 \pm 2.1$ & 0.405 & $108.0 \pm 30.9$ & $130.6 \pm 40.0$ & 0.140 \\
\hline $\mathrm{pH}$ & $7.27 \pm 0.14$ & $7.32 \pm 0.12$ & 0.416 & $7.37 \pm 0.05$ & $7.44 \pm 0.11$ & 0.134 \\
\hline $\mathrm{HCO}_{3}(\mathrm{mmol} / \mathrm{L})$ & $14.2 \pm 4.6$ & $12.8 \pm 4.8$ & 0.500 & $19.2 \pm 4.5$ & $18.93 \pm 3.86$ & 0.904 \\
\hline Base deficit $(\mathrm{mmol} / \mathrm{L})$ & $11.5 \pm 5.1$ & $11.7 \pm 5.8$ & 0.918 & $5.3 \pm 3.8$ & $4.1 \pm 2.8$ & 0.427 \\
\hline Glucose (mg/dL) & $103.4 \pm 54.5$ & $126.6 \pm 67.8$ & 0.375 & $149.5 \pm 104.7$ & $143.8 \pm 109.4$ & 0.901 \\
\hline Creatinine (mg/dL) & $0.85 \pm 0.19$ & $0.89 \pm 0.13$ & 0.537 & $0.52 \pm 0.17$ & $0.62 \pm 0.37$ & 0.469 \\
\hline Calcium (mg/dL) & $9.24 \pm 0.78$ & $9.28 \pm 0.62$ & 0.911 & $9.36 \pm 0.82$ & $8.96 \pm 0.71$ & 0.242 \\
\hline AST (U/L) & $53.9 \pm 23.3$ & $216.0 \pm 302.8$ & 0.147 & $47.9 \pm 27.4$ & $82.9 \pm 63.6$ & 0.150 \\
\hline $\operatorname{ALT}(\mathrm{U} / \mathrm{L})$ & $14.6 \pm 4.8$ & $59.4 \pm 101.7$ & 0.223 & $19.1 \pm 14.9$ & $56.0 \pm 100.9$ & 0.306 \\
\hline $\mathrm{LDH}(\mathrm{IU} / \mathrm{L})$ & $1,083.1 \pm 573.1$ & $2,303.2 \pm 2,307.2$ & 0.156 & $1,237.8 \pm 584.6$ & $2,014.8 \pm 1,520.2$ & 0.175 \\
\hline $\mathrm{CPK}(\mathrm{U} / \mathrm{L})$ & $1,140.2 \pm 1,232.5$ & $2,503.7 \pm 3,636.4$ & 0.221 & $544.6 \pm 356.9$ & $667.8 \pm 725.1$ & 0.591 \\
\hline $\mathrm{CRP}(\mathrm{mg} / \mathrm{L})$ & $0.59 \pm 0.98$ & $2.66 \pm 4.74$ & 0.231 & $24.87 \pm 32.65$ & $8.29 \pm 4.85$ & 0.148 \\
\hline $\operatorname{WBC}\left(10^{3} / \mathrm{L}\right)$ & $13.62 \pm 59.88$ & $23.81 \pm 78.95$ & 0.082 & $9.55 \pm 3.41$ & $14.22 \pm 4.32$ & 0.009 \\
\hline Hematocrits (\%) & $47.25 \pm 10.12$ & $50.54 \pm 2.74$ & 0.354 & $40.81 \pm 4.85$ & $40.16 \pm 5.42$ & 0.767 \\
\hline Platelet $\left(10^{9} / \mathrm{L}\right)$ & $237.21 \pm 76.13$ & $232.78 \pm 53.47$ & 0.881 & $112.71 \pm 54.86$ & $133.22 \pm 37.77$ & 0.339 \\
\hline PT (sec) & $15.53 \pm 2.922$ & $17.43 \pm 4.86$ & 0.251 & - & - & - \\
\hline aPTT (sec) & $54.49 \pm 14.96$ & $58.10 \pm 18.50$ & 0.612 & - & - & - \\
\hline
\end{tabular}

Values are expressed as mean \pm standard deviation.

Abbreviations: $\mathrm{HCO}_{3}$, bicarbonate; AST, aspartate transaminase; ALT, alanine transaminase; $\mathrm{LDH}$, lactate dehydrogenase; CPK, creatine phosphokinase; CRP, C-reactive protein; WBC, white blood cell; PT, partial thromboplastin time; aPTT, activated partial thromboplastin time.

Table 4. Cerebral Lesions Revealed by Magnetic Resonance Imaging

\begin{tabular}{lcc}
\hline & Normal $(\mathrm{n}=14)$ & Abnormal $(\mathrm{n}=10)$ \\
\hline Parenchymal lesion & 2 & 7 \\
BGT & 0 & 2 \\
WM & 2 & 5 \\
Hemorrhage & 1 & 10 \\
Subdural hematoma & 1 & 5 \\
Scattered white matter & 0 & 3 \\
Intraventricular & 0 & 2 \\
Parenchymal lesion only & 2 & 0 \\
Hemorrhagic lesion only & 1 & 3 \\
\hline
\end{tabular}

Cerebral magnetic resonance imaging in the second week revealed that all 10 infants (100\%) in the abnormal group had abnormal lesions, whereas 11 of 14 infants (78.6\%) in the normal group had normal lesions $(P<0.001)$. In the normal group, three infants had abnormal lesions (two WM, one subdural). In the abnormal group, lesions in BGT were detected in two infants (20\%) and in WM, in five infants (50\%). In the abnormal group, hemorrhagic regions were observed in 10 of 10 infants, whereas subdural hematoma was observed in five infants (50\%), scattered white matter hemorrhage was observed in three infants, and intraventricular hemorrhage was observed in two infants. Three infants in the abnormal group showed only hemorrhagic lesions.

Abbreviations: BGT, basal ganglia and thalamus; WM, white matter.
달장애를 최소화할 수 있는 가장 최신의 표준 치료법이다 ${ }^{1-4)}$. 하지 만 이러한 치료의 도입에도 불구하고 저산소허혈뇌증 신생아의 약 $40 \%$ 가 18 개월 시기 신경 발달장애를 겪고 있으며, 이러한 장애가 학 동기까지 지속되는 것으로 보고되고 있다 ${ }^{3-5)}$. 이러한 결과는 아직 저 체온치료만으로는 신생아 저산소허혈뇌증의 온전한 치료방법이 아 님을 의미하며, 저체온치료 이외에 추가적인 보완 치료에 대한 연구가 필요하다는 것을 보여주는 증거가 될 수 있다. 현재 신생아 저산소허 혈뇌증에 대한 저체온치료는 손상의 원인, 정도, 시점 및 기간이 서 로 다른 복합적으로 진행된 뇌증을 획일화된 기준으로 중등도 및 중 증으로 구분해서 동일한 방법의 저체온치료를 적용하고 있다 ${ }^{10,11)}$.

이는 태아기 손상 시점, 정도 및 유형과 이에 대한 태아의 적응 기 전 및 적응 정도, 치료에 대한 반응 및 효과 등을 개별적으로 평가하 기가 어렵기 때문이다. 만약 출생시점의 손상 정도를 평가할 수 있 고, 치료 과정 중의 치료 효과에 대한 예측인자가 있다면 조금 더 개 별적이고 그룹화된 치료 방침을 세우기가 용이할 것이다 ${ }^{(-8)}$.

신생아 저산소허혈뇌증은 출생 후 진단 시의 임상적 특성을 판단 하는 Sarnat stage가 사망이나 신경학적 예후의 주요 지표로 사용되 어 왔다 ${ }^{12)}$. 그러나 같은 중등도나 중증의 Sarnat기로 판정받은 신생 아도 이후 신경학적 발달의 예후에 차이가 있으며 특히 명확한 치료 기준 하에 같은 방법으로 저체온치료를 받은 신생아들도 각각 예후 가 다른 결과들을 볼 수 있다 ${ }^{12-14}$. 저자들은 저체온치료를 받은 각 대 
상아들의 재태기간, 출생체중, 성별, 분만 장소, 분만 방법, 분만 중 태아의 뇌 손상을 유발할 수 있는 주요 위험 사건, 신생아 저산소허 혈뇌증 중증도, 출생 후 저체온치료 시작 시간, 계면활성제 투여 유 무 등 출생 전, 후의 임상적 특성을 비교해 보았으나 정상 발달군과 비정상 발달군 간 각 항목별로 의미 있는 차이가 없었으며 이러한 결과는 다른 유사 연구들의 결과와도 특별한 차이를 보이지 않았다 ${ }^{15-18)}$. 신생아 저산소허혈뇌증의 진단에 중요한 요소인 아프가 점수 는 통계에서 제외하였는데 대상아 24명 중 14 명 $(58.3 \%)$ 이 외부 병 원에서 전원 된 환아로 수치를 신뢰할 수 없었기 때문이다. 저체온 치료를 받는 과정의 신생아에게 유병률이 높은 증상은 저혈압, 혈액 응고장애, 저혈당, 감염, 동성서맥, 기타 부정맥 등으로 알려져 있으 며 태변 흡인성폐렴, 폐출혈, 폐고혈압, 폐공기 누출, 폐렴, 후기 패 혈증, 신부전증, 괴사성 장염 등의 임상 질환이 동반되는 것으로 보 고되고 있다 ${ }^{19-21)}$. 저자들은 치료 과정 중의 임상 증상, 동반 질환, 합 병증 등이 신경학적인 예후에 관련이 있는지를 알아보기 위하여 저 체온치료 중 최저 혈압, 최저 맥박수, 승압제 투여, 스테로이드 투여, 신생아 경련, 폐공기 누출, 폐출혈, 폐동맥 고혈압증 등의 빈도를 비 교하여 보았으나 정상 발달군과 비정상 발달군 간 유의한 차이가 없 었다. 기계적 환기 치료를 받은 기간 및 입원기간 또한 양 군 간 유의 한 차이가 없었다. 이들 동반 증상들 중 저체온으로 인한 증상은 동 성서맥과 혈소판감소증 만이 알려져 있고 ${ }^{22}$ 다른 질환들은 주로 저 산소허혈뇌증을 일으킨 병인과 관련이 있는 것으로 알려져 있으나 ${ }^{19-22)}$ 저자들이 비교 분석한 증상들 중 특별히 신경 발달의 예후에 관 련된 동반 증상은 확인되지 않았다. 다만 본 결과는 각 증상별 대상 아 수가 적어 통계적으로 의미를 두기가 어려운 문제가 있다. 이후 대규모의 환아를 대상으로 한 전향적 연구가 필요할 것으로 생각된 다. 경련 증상은 저체온치료의 적용기준이 되는 중요한 징후로서 경 련이 확인되면 중등도 이상의 뇌증으로 판단할 수 있다. 저체온치료 시 신생아 경련이 나쁜 예후의 예측인자가 될 수 있다는 보고가 있으 나 연구마다 다른 결과를 보였으며 ${ }^{23-26)}$ 본 연구에서는 EEG 및 $\mathrm{aEEG}$ 의 연속 감시로 관찰한 경련의 발생이 뇌신경 발달의 예후에 유의한 차이가 없었다. 저산소허혈뇌증 신생아의 신경학적 중증도 및 예후 를 예측할 수 있는 생화학적 예측 인자는 아직 확실하게 보고된 것이 없다 ${ }^{27-30)}$. 저자들은 각 군의 저체온치료 이전과 3 일간의 치료 이후 의 혈액학, 혈액화학, 혈액가스, 혈액응고, C-반응성단백(C-reactive protein) 검사 상 양 군 간의 차이가 있는지 알아보았다. 분석 결과 치료 이전의 각 혈액의 수치들은 모두 양 군 간 유의한 차이가 없었 으며 치료 완료 후 시행된 혈액 검사에서 백혈구 수치를 제외한 다른 수치들 또한 양 군 간에 유의한 차이가 없었다. C반응성단백의 수치 는 양 군 모두 저체온치료 이전보다 이후에 증가되었으나 통계적으 로 유의한 차이는 보이지 않았다. 또한 본 연구의 결과에서 치료 이 전 백혈구와 혈소판 수치가 치료 후 감소된 것을 확인할 수 있었는 데 이는 저체온치료가 $\mathrm{C}$ 반응성단백의 염증반응을 둔화시키고 백혈
구와 혈소판 수치를 감소시킨다는 Chakkarapani 등 ${ }^{31}$ 의 보고와 유 사하다. 백혈구 수치의 경우 저체온치료 이전 양 군 간 차이가 없었 으나 치료 이후 비정상 발달군이 정상 발달군에 비하여 통계적으로 유의하게 높은 결과를 보인 것은 정상 발달군이 비정상 발달군에 비 하여 백혈구 수치 증가에 대한 억제가 더 잘 이루어진 것으로 생각할 수 있다. 그러나 회귀분석 결과 백혈구 수치의 차이는 신경 발달의 예후 예측인자로 유의하지 않다는 결과를 보여 추후 더 많은 환아를 대상으로 한 연구가 필요할 것으로 생각된다. 영상학적인 예측인자 로서 뇌 MRI 및 자기공명분광법(magnetic resonance spectroscopy) 은 신생아 허혈뇌증의 중증도, 신경학적 결과 및 저체온치료 후의 치 료 반응결과를 잘 예측할 수 있는 것으로 받아 들여지고 있다 ${ }^{32-35)}$. 저 자들의 연구 기관에서는 자기공명분광법을 시행하지 않고 있어 MRI 결과만을 비교하였다. 연구 결과 정상 발달군은 14 명 중 3 명 $(21.4 \%)$ 만이 비정상 뇌 MRI의 소견을 보인 반면 비정상 발달군은 10 명 중 10명(100\%) 모두 비정상 뇌 MRI의 소견을 보여 비정상 발달군에 대 한 비정상 MRI의 민감도는 $100 \%$ 특이도는 $78.57 \%$ 로 연구된 인자들 중 유일하게 의미 있는 예후인자임을 알 수 있었다. MRI 소견을 분 석해 보면 비정상 발달군은 10 명 중 7 명에서 뇌실질의 병변과 출혈 이 동반 되었으나 3 명의 영아는 실질손상 없이 경막하 출혈 소견만 보였다. 정상 발달군 중 2 명은 출혈소견 없이 뇌실질의 이상소견만 보였고 1명이 경막하 출혈소견을 보였다. MRI 손상 형태에 따른 예 후의 차이는 대상군의 수가 적어 예후에 대해 논하는 것에 대하여 제 한이 있었다. 환아들의 뇌 병변 형태에서 환아의 뇌 실질에 병변이 있던 환아 뿐 아니라 출혈 등의 병변이 있는 환아를 포함한 비정상군 에서 발달에 문제가 있는 것은 출혈도 위험인자가 될 수 있는 가능성 이 있음을 시사한다고 볼 수 있다. 특히 뇌출혈의 경우 MRI 시행 시 기가 저체온치료 완료 이후 기간이어서 출혈 시점이 저체온치료 이 전인지 치료 과정 중 혹은 재가온 과정 중인지 알기가 어려운 문제 가 있다. 저체온치료 시 혈소판 감소와 혈액응고장애로 인한 혈전 및 출혈의 위험이 있다는 것은 이미 보고 되어있으며 ${ }^{1)}$ 최근에는 기 저의 저산소허혈성뇌증에 저체온치료로 인한 출혈 경향이 부과되어 생기는 뇌손상에 대한 우려가 보고되고 있어 ${ }^{36,37)}$ 저자들의 MRI 결과 와 같이 뇌실질의 손상 소견 없이 경막하혈종의 소견만을 보인 대상 군에 대하여 출혈 시점과 출혈과 관련된 저체온치료의 영향에 대한 연구도 진행되어야 할 것으로 생각된다.

본 연구는 후향적 연구로 해석의 제한이 있으며 많은 유사한 연구 들과 같이 표본 크기가 작은 제한이 있다. 대상아들 중 외부 병원에 서 출생 후 전원 된 수가 많은 이유로 출생 전 및 분만 과정, 분만 직 후의 상태에 관한 정보가 완전하지 않으며 특히 아프가점수의 경우 환아의 증상과 불일치한 경우가 많아 데이터로서의 가치가 없는 것 으로 판단하였다. 신경학적인 검사 방법이 대상아 전체에 같은 방법 으로 적용되지 않았고 시기도 18 개월에서 24 개월까지 범위가 넓게 시행되었다. 단, 대부분의 대상아에게 재활의학과 진료 및 K-DST 검 
사를 시행하였고 신경 발달장애군의 경우 모두 재활치료를 진행하 여 K-DST와 베일리 검사, 신경 발달 검사의 결과들을 고려하여 평가 하였다.

본 연구에서는 저산소허혈뇌증 신생아의 전신 저체온치료 후 신 경 발달의 예후를 예측할 수 있는 요인을 알아보기 위하여 분만 및 출생과 관련한 임상적 특성과 치료 과정 중의 임상증상 및 검사결 과, 치료 이전과 치료 이후의 혈액 및 생화학적 결과들을 분석하였으 며 신경 발달 예후와 관련이 있는 인자로서 뇌 MRI가 가장 민감도 및 특이도가 높은 검사인 것으로 확인하였다. 그러나 MRI 결과는 치료 이전이나 치료과정 중의 상태보다는 치료 이후의 결과를 보고 예측 한다는 제한점이 있다. 향후 저산소허혈뇌증 신생아의 초기 신경학 적 예측인자를 찾기 위한 대규모의 전향적 무작위 비교 연구가 필요 할 것으로 생각된다.

\section{이해관계}

본 저자는 이 논문과 관련된 이해관계가 없음.

\section{REFERENCES}

1. Jacobs SE, Berg M, Hunt R, Tarnow-Mordi WO, Inder TE, Davis PG. Cooling for newborns with hypoxic ischaemic encephalopathy. Cochrane Database Syst Rev 2013;1:CD003311.

2. Committee on Fetus and Newborn, Papile LA, Baley JE, Benitz W, Cummings J, Carlo WA, et al. Hypothermia and neonatal en cephalopathy. Pediatrics 2014;133:1146-50.

3. Azzopardi D, Strohm B, Marlow N, Brocklehurst P, Deierl A, Eddama O, et al. Effects of hypothermia for perinatal asphyxia on childhood outcomes. N Engl J Med 2014;371:140-9.

4. Shankaran S, Pappas A, McDonald SA, Vohr BR, Hintz SR, Yolton $\mathrm{K}$, et al. Childhood outcomes after hypothermia for neonatal encephalopathy. N Engl J Med 2012;366:2085-92.

5. Tagin MA, Woolcott CG, Vincer MJ, Whyte RK, Stinson DA. Hypothermia for neonatal hypoxic ischemic encephalopathy: an updated systematic review and meta-analysis. Arch Pediatr Adolesc Med 2012;166:558-66.

6. Martinello K, Hart AR, Yap S, Mitra S, Robertson NJ. Management and investigation of neonatal encephalopathy: 2017 update. Arch Dis Child Fetal Neonatal Ed 2017;102:F346-58.

7. Edwards AD, Brocklehurst P, Gunn AJ, Halliday H, Juszczak E, Levene $M$, et al. Neurological outcomes at 18 months of age after moderate hypothermia for perinatal hypoxic ischaemic encephalopathy: synthesis and meta-analysis of trial data. BM] 2010;340:c363.
8. Guillet R, Edwards AD, Thoresen M, Ferriero DM, Gluckman PD, Whitelaw A, et al. Seven- to eight-year follow-up of the CoolCap trial of head cooling for neonatal encephalopathy. Pediatr Res 2012;71:205-9.

9. Merchant N, Azzopardi D. Early predictors of outcome in infants treated with hypothermia for hypoxic-ischaemic encephalopathy. Dev Med Child Neurol 2015;57 Suppl 3:8-16.

10. Volpe JJ. Neonatal encephalopathy: an inadequate term for hypoxic-ischemic encephalopathy. Ann Neurol 2012;72:156-66.

11. Dammann O, Ferriero D, Gressens P. Neonatal encephalopathy or hypoxic-ischemic encephalopathy? Appropriate terminology matters. Pediatr Res 2011;70:1-2.

12. Sarnat HB, Sarnat MS. Neonatal encephalopathy following fetal distress. A clinical and electroencephalographic study. Arch Neurol 1976;33:696-705.

13. Pierrat V, Haouari N, Liska A, Thomas D, Subtil D, Truffert P, et al. Prevalence, causes, and outcome at 2 years of age of newborn encephalopathy: population based study. Arch Dis Child Fetal Neonatal Ed 2005;90:F257-61.

14. Simon NP. Long-term neurodevelopmental outcome of asphyxiated newborns. Clin Perinatol 1999;26:767-78.

15. van Laerhoven $H$, de Haan TR, Offringa $M$, Post $B$, van der Lee $\mathrm{JH}$. Prognostic tests in term neonates with hypoxic-ischemic encephalopathy: a systematic review. Pediatrics 2013;131:88-98.

16. Massaro AN. MRI for neurodevelopmental prognostication in the high-risk term infant. Semin Perinatol 2015;39:159-67.

17. Shankaran S. Outcomes of hypoxic-ischemic encephalopathy in neonates treated with hypothermia. Clin Perinatol 2014;41:14959.

18. Shankaran S. Therapeutic hypothermia for neonatal encephalopathy. Curr Opin Pediatr 2015;27:152-7.

19. Azzopardi D, Strohm B, Linsell L, Hobson A, Juszczak E, Kurinczuk JJ, et al. Implementation and conduct of therapeutic hypothermia for perinatal asphyxial encephalopathy in the UK: analysis of national data. PLoS One 2012;7:e38504.

20. Sarkar S, Barks J. Management of neonatal morbidities during hypothermia treatment. Semin Fetal Neonatal Med 2015;20:97102.

21. Armstrong K, Franklin O, Sweetman D, Molloy EJ. Cardiovascular dysfunction in infants with neonatal encephalopathy. Arch Dis Child 2012;97:372-5.

22. Jacobs SE, Morley CJ, Inder TE, Stewart MJ, Smith KR, McNamara PJ, et al. Whole-body hypothermia for term and near-term newborns with hypoxic-ischemic encephalopathy: a randomized controlled trial. Arch Pediatr Adolesc Med 2011;165:692-700.

23. Glass HC, Hong KJ, Rogers EE, Jeremy RJ, Bonifacio SL, Sullivan JE, et al. Risk factors for epilepsy in children with neonatal encephalopathy. Pediatr Res 2011;70:535-40.

24. Kwon JM, Guillet R, Shankaran S, Laptook AR, McDonald SA, 
Ehrenkranz RA, et al. Clinical seizures in neonatal hypoxicischemic encephalopathy have no independent impact on neurodevelopmental outcome: secondary analyses of data from the neonatal research network hypothermia trial. J Child Neurol 2011;26:322-8.

25. Goeral K, Urlesberger B, Giordano V, Kasprian G, Wagner M, Schmidt L, et al. Prediction of outcome in neonates with hypoxic-ischemic encephalopathy II: role of amplitude-integrated electroencephalography and cerebral oxygen saturation measured by near-infrared spectroscopy. Neonatology 2017;112 193-202.

26. Chandrasekaran M, Chaban B, Montaldo P, Thayyil S. Predictive value of amplitude-integrated EEG (aEEG) after rescue hypothermic neuroprotection for hypoxic ischemic encephalopathy: a meta-analysis. J Perinatol 2017;37:684-9.

27. Roka A, Beko G, Halasz J, Toldi G, Lakatos P, Azzopardi D, et al. Changes in serum cytokine and cortisol levels in normothermic and hypothermic term neonates after perinatal asphyxia. Inflamm Res 2013;62:81-7.

28. Massaro AN, Chang T, Kadom N, Tsuchida T, Scafidi J, Glass P, et al. Biomarkers of brain injury in neonatal encephalopathy treated with hypothermia. J Pediatr 2012;161:434-40.

29. Jenkins DD, Rollins LG, Perkel JK, Wagner CL, Katikaneni LP, Bass WT, et al. Serum cytokines in a clinical trial of hypothermia for neonatal hypoxic-ischemic encephalopathy. J Cereb Blood Flow Metab 2012;32:1888-96.

30. Pepys MB, Hirschfield GM. C-reactive protein: a critical update. J Clin Invest 2003;111:1805-12.
31. Chakkarapani E, Davis J, Thoresen M. Therapeutic hypothermia delays the C-reactive protein response and suppresses white blood cell and platelet count in infants with neonatal encephalopathy. Arch Dis Child Fetal Neonatal Ed 2014;99:F458-63.

32. Alderliesten T, de Vries LS, Benders MJ, Koopman C, Groenendaal F. MR imaging and outcome of term neonates with perinatal asphyxia: value of diffusion-weighted MR imaging and (1) H MR spectroscopy. Radiology 2011;261:235-42.

33. Shankaran S, Barnes PD, Hintz SR, Laptook AR, Zaterka-Baxter $\mathrm{KM}, \mathrm{McDonald}$ SA, et al. Brain injury following trial of hypothermia for neonatal hypoxic-ischaemic encephalopathy. Arch Dis Child Fetal Neonatal Ed 2012;97:F398-404.

34. Corbo ET, Bartnik-Olson BL, Machado S, Merritt TA, Peverini R, Wycliffe N, et al. The effect of whole-body cooling on brain metabolism following perinatal hypoxic-ischemic injury. Pediatr Res 2012;71:85-92.

35. Cheong JL, Coleman L, Hunt RW, Lee KJ, Doyle LW, Inder TE, et al. Prognostic utility of magnetic resonance imaging in neonatal hypoxic-ischemic encephalopathy: substudy of a randomized trial. Arch Pediatr Adolesc Med 2012;166:634-40.

36. Chiang MC, Lin KL, Lin JJ, Lien R. Cranial hemorrhage and outcome of neonates treated with therapeutic hypothermia for hypoxic ischemic encephalopathy. J Paediatr Child Health 2018;54(Suppl 1):67.

37. Wang D, McMillan H, Bariciak E. Subdural haemorrhage and severe coagulopathy resulting in transtentorial uncal herniation in a neonate undergoing therapeutic hypothermia. BMJ Case Rep 2014;2014:bcr2013203080. 